\title{
PENGARUH TUNJANGAN SERTIFIKASI TERHADAP KINERJA GURU SEKOLAH DASAR (SD) NEGERI KOTA BANDAR LAMPUNG
}

\author{
Sodirin $^{(1)}$, Herman Erawan ${ }^{(2)}$ \\ Fakultas Ekonomi Universitas Sang Bumi Ruwa Jurai \\ sodirin@fe.saburai.ac.id
}

\begin{abstract}
Abstrak. Penelitian ini bertujuan untuk mengetahui sertifikasi guru terhadap kinerja guru. Penelitian dilakukan pada guru-guru di Sekolah Dasar di Kota Bandar Lampung dimana responden dilakukan terhadap guru guru yang sudah lulus atau guru guru yang sudah mendapatkan sertifikasi. Melalui sertifikasi yang sudah didapatkan, diharapkan guru mampu memberikan pengaruh terhadap kinerja responden yang semakin baik sehingga menghasilkan tenaga pendidik yang profesional. Jenis penelitian adalah eksplanatory dengan pendekatan secara kuantitatif. Sampel dalam penelitian sejumlah 67 responden. Teknik pengumpulan data dalam penelitian ini menggunakan kuesioner, wawancara dan dekomentasi, sedangkan uji pengaruh dilakukan dengan menggunakan regresi linier sederhana. Hasil perhitungan korelasi antar variabel menunjukan bahwa adanya hubungan yang signifikan antara tujangan sertifikasi guru dengan kinerja guru. Secara keseluruhan hubungan antara dua variabel tersebut adalah positif, hal ini menunjukkan bahwa semakin tinggi nilai sertifikasi guru maka semakin tinggi pula kinerja guru. Besarnya korelasi antara variabel sertifikasi guru dengan variabel kinerja guru adalah 0.449 . Besarnya pengaruh antara variabel sertifikasi guru dengan variabel kinerja guru adalah $44.9 \%$. Maka dapat diketahui bahwa terdapat pengaruh antara sertifikasi guru terhadap kinerja guru.
\end{abstract}

Kata kunci: Guru, Kinerja, Pengaruh, Sertifikasi.

\section{PENDAHULUAN}

Kehidupan manusia tidak lepas dari proses sosialisasi.Beger (dalam Sunarto, 2004 ) mendefinisikan sosialisasi sebagai “ a procces by which a child learns to be participant member of society ", yaitu proses dimana seorang anak belajar menjadi seorang anggota yang berpatisipasi dalam masyarakat. Proses sosialisasi ini, yaitu keluarga, teman bermain, sekolah dan media masa ( Lesy Gustina, 2016 ).

Sekolah adalah salah satu agen sosialisasi dalam bentuk system pendidikan formal. Ketika seorang anak masuk sekolah, maka akan bertemu dengan temanteman yang baru dan tentu saja guru-guru yang akan membimbing anak ketika berada di sekolah. Guru merupakan seorang administrator, informatory dan konduktor yang memiliki peran penting di sekolah. Sebagai pendidik dan pembangun generasi baru, diharapkan guru dapat bertingkahlaku yang bermoral tinggi karena apa yang dilakukan guru akan menjadi contoh bagi anak muridnya.

Menurut Djamarah ( dalam Saniyah, 2008 ) guru adalah pemegang posisi dan peranan penting, bukan hanya di sekolah tetapi juga di dalam dunia pendidikan. Guru merupakan cermin pribadi bagi anak didiknya, dari membimbing, mendengarkan keluhan, menasehati, bersenda gurau, Manusia dalam kehidupannya tidak lepas dari proses sosialisasi. Beger ( dalam Sunarto, 2004 dan membantu anak dalam menghadapi kesulitan yang dapat menghambat aktivitas belajarnya. Sebagai pendidik/pengajar, guru merupakan salah satu faktor penentu keberhasilan setiap upaya pendidikan.

Itulah sebabnya dalam setiap inovasi pendidikan, khususnya dalam perbaikan kurikulum, selalu bermuara pada faktor 
guru. Guru merupakan ujung tombak dalam pembangunan pendidikan nasional, utamanya dalam membangun dan meningkatkan kualitas sumberdaya manusia dalam pendidikan formal. Guru mempunyai kedudukan sebagai tenaga profesional pada jenjang pendidikan usia dini, pendidikan dasar, dan pendidikan menengah pada jalur pendidikan formal yang diangkat sesuai dengan peraturan perundang-undangan (UU SISDIKNAS, dalam Suniyah 2008).

Pemerintah saat ini telah memberikan perhatian yang lebih dalam masalah pendidikan, khususnya masalah kesejahteraan guru. Dahulu, menjadi seorang guru dapat dikatakan masih sulit untuk mendapatkan kesejahteraan, dan satusatunya yang bias membuat para guru dari kesulitan menjalani kehidupan menjadi guru karena label " Pahlawan Tanpa Tanda Jasa" yang diberikan kepada mereka.

Seiring dengan pembaharuan dalam system pendidikan Indonesia, memperbaiki kesejahteraan guru adalah tujuan utama pemerintah saat ini dengan maksud agar tujuan pendidikan Nasional yaitu menghasilkan guru yang berkompetensi dalam bidangnya dan menghasilkan sumberdaya manusia yang mampu bersaing di era global dapat tercapai. Salah satu upaya pemerintah untuk memperbaiki kesejahteraan guru adalah dengan memberikan sertifikasi bagi guru. Sertifikasi bagi guru ini diadakan dengan tujuan untuk menghasilkan guru-guru yang berkompeten dalam bidang tugasnya masing-masing dan meningkatkan kesejahteraan guru.

Sertifikasi guru merupakan tunjangan yang ditujukan kepada para guru yang telah lulus dalam tes sertifikasi. Program ini ternyata dapat dikatakan sebagai salah satu motivasi seorang guru untuk dapat meningkatkan kinerjanya dalam bekerja. Pelaksanaan program sertifikasi guru dilaksanakan sejak tahun 2007 setelah diterbitkannya Peraturan Mendiknas Nomor 18 Tahun 2007 tentang Sertifikasi Bagi Guru Dalam Jabatan. Progran sertifikasi ini dilaksanakn dengan tujuan untuk meningkatkan kompetensi guru sebagai tenaga pendidik yang professional. Melalui sertifikasi ini guru dituntut agar bersungguh-sungguh menjalankan tugasnya sebagai guru dan mengerahkan segala pemikiran serta kreatifitasnya bagi pendidikan. Program sertifikasi diberlakukan untuk para guru yang memiliki masa kerja minimal 5 Tahun dengan usia maksimal 50 tahun (KEMDIKBUD, 2013).

Sertifikasi adalah salah satu bentuk penghargaan dari pemerintah atas pencapaian kinerja guru. Program sertifikasi menuntut para guru untuk dapat melaksanakan kewajibannya sebagai tenaga pendidik yang professional. Jika para guru tidak dapat memenuhi kewajibannya, maka secara otomatis pemerintah akan memberhentikan tunjungan sertifikasinya. Sertifikasi guru sebagai upaya peningkatan mutu guru diharapkan dapat meningkatkan mutu pembelajaran dan mutu pendidikan di Indonesia secara berkelanjutan.

Melalui program sertifikasi yang diadakan oleh pemerintah ini, para guru akhirnya lebih termotivasi untuk meningkatkan profesionalismenya dalam bekerja. Syarat utama untuk mengikuti program sertifikasi adalah harus memiliki kualifikasi akademik yang telah ditetapkan oleh pemerintah. Setelah lulus dari uji kompetensi program sertifikasi, apabila guru lulus dalam persyaratan dan ujian sertifikasi, maka guru akan mempunyai sertifikat sebagai bukti keprofesionalannya sebagai tenaga pengajar. Manfaat yang diharapkan dengan diadakannya program sertifikasi adalah memunculkan para guru untuk meningkatkan kualitas dirinya sebagai tenaga professional.

Berdasarkan Data jumlah SD Negeri Kota Bandar Lampung berjumlah 187 
sekolah dengan jumlah guru yang PNS 2.340 guru. Tetapi peneliti/penulis mengambil kuota/ Sampel sebanyak 30 sekolah dengan 67 guru kelas VI (enam) dikarenakan guru kelas enam yang jelas sekali dapat kita lihat bagaimana kinerjanya untuk menghasilkan anak-anak kelas enam dapat lulus untuk melanjutkan pendidikan kejenjang lebih tinggi dengan nilai yang memuaskan atau dengan nilai yang baik yang sesuai dengan standar Mendikbud. Sebab selama ini Sertifikasi guru yang sudah berlangsung selama 10 tahun tidak selamanya setiap tahun menghasilkan kinerja guru yang memuaskan, hal ini dihubungkan dengan naik turunnya nilai kelulusan peserta didik tingkat sekolah dasar (SD).

Seperti harapannya bahwa tujuan utama diadakan program sertifikasi adalah untuk meningkatkan pengetahuan, kinerja, kreatifitas, serta mampu menjalankan fungsi-fungsi lainnya yang berhubungan dengan proses belajar mengajar. Berdasarkan latar belakang masalah di atas, peneliti tertarik untuk mengungkapkan fenomena ini kedalam sebuah bentuk penelitian, yang berjudul: "Pengaruh Tunjangan Sertifikasi Terhadap Kinerja guru Sekolah Dasar ( SD) Negeri Kota Bandar Lampung".

\section{KAJIAN TEORI}

\section{Defenisi Sertifikasi Guru}

Sertifikasi guru merupakan kebijakn yang sangat strategis, karena langkah dan tujuan melakukan sertifikasi guru untuk meningkatkan kualitas guru, memiliki kompetensi, mengangkat harkat dan wibawa guru sehingga guru lebih dihargai dan untuk meningkatkan kualitas pendidikan di Indonesia ( Sanaky, 2004).

Menurut Mulyasa ( 2007), Sertifikasi guru merupakan proses uji kompetensi bagi calon guru atau guru yang ingin memperoleh pengakuan dan atau meningkatkan kompetensi aesuai profesi yang dipilihnya. Reprensentasi pemenuhan standar kompetensi yang telah ditetapkan dalam sertifikasi guru adalah sertifikat kompetensi pendidik.

Sertifikat ini sebagai bukti pengakuan atas kompetensi guru atau calon guru yang memenuhi standar untuk melakukan pekerjaan profesi guru pada jenis dan jenjang pendidikan tertentu. Dengan kata lain sertifikasi guru merupakan pemenuhan kebutuhan untuk meningkatkan kompetensi professional. Oleh karena itu, proses sertifikasi dipandang sebagai bagian esensial dalam upaya memperoleh sertifikat kompetensi sesuai dengan standar yang telah ditetapkan.

National Commission on Education Services (NCES) memberikan pengertian sertifikat guru secara lebih umum. Sertifikat guru merupakan prosedur untuk menentukan apakah seorang calon guru layak diberikan izin dan kewenangan untuk mengajar. Hal ini diperlukan karena lulusan lembaga pendidikan tenaga keguruan sangat bervariasi, baik di kalangan perguruan tinggi negeri maupun swasta ( NES dalam Mulyasa, 2007).

Maka, dapat disimpulkan bahwa program sertifikasi guru adalah suatu program yang dilakukan oleh pemerintah di bawah kuasa Dinas Pendidikan Indonesia dalam upayaa meningkatkan kualitas pendidikan di Indonesia yang dilaksanakn melalui LPTK yang terakreditasi dan ditetapkan pemerintah dengan pemberian sertifikat kepada guru yang telah berhasil mengikuti program tersebut.

\section{Prinsip Sertifikasi Guru}

Menurut Jalal ( 2007), prinsip sertifikasi guru adalah sebagai berikut:

1. Dilaksanakan secara objektif, transparan dan akuntabel. Objektif yaitu mengacu kepada proses 
perolehan sertifikat pendidik yang impartial, tidak diskriminatif, dan memenuhi standar pendidikan nasional. Transparan yaitu mengacu kepada proses sertifikasi yang memberikan peluang kepada semua guru. Akuntabel merupakan proses sertifikasi yang dipertanggungjawabkan kepada pemangku kepentingan pendidikan secara administrative, finansial dan akademik.

2. Berujung pada peningkatan mutu pendidikan nasional melalui peningkatan guru dan kesejahteraan guru.

3. Dilaksanakan sesuai dengan peraturan dan perundang-undangan. Program sertifikasi pendidik dilaksanakn dalam rangka memenuhi amanat UndangUndang Republik Indonesia Nomor 20 Tahun 2003 tentang Sistem Pendidikan Nasional , Undang-Undang Republik Indonesia Nomor 14 Tahun 2005 tentang Guru dan Dosen, dan Peraturan Pemerintah Nomor 19 Tahun 2005 tentang Standar Nasional Pendidikan.

4. Dilaksanakan secara terencana dan sistematis. Agar pelaksanaan program sertifikasi dapat berjalan dengan efektif dan efesien harus direncanakn secara matang dan sistematis. Kompetensi guru mencakup empat pokok yaitu, kompetensi pedagogic. Kepribadian, social dan professional, sedangkan standar kompetensi guru mencakup kompetensi ini guru yang kemudian dikembangkan menjadi kompetensi guru TK/RA, guru kelas SD/MI dan guru mata pelajaran. Untuk memberikan sertifikat pendidik kepada guru, perlu dilakukan uji kompetensi melalui penilaian portofolio.
5. Jumlah peserta sertifikasi guru ditetapkan oleh pemerinah. Untuk alas an efektifitas dan efesiensi pelaksanaan sertifikasi guru serta penjaminan kualitas hasil sertifikasi, jumlah perserta pendidikan profesi dan uji kompetensi setiap tahunnya ditetapkan oleh pemerintah.

\section{Pengertian Guru}

Guru adalah suatu sebutan bagi jabatan, dan profesi bagi sesorang yang mengabdikan dirinya dalam bidang pendidikan melalui interaksi edukatif secara terpola, formal dan sistematis. Dalam UU Nomor 14 Tahun 2005 tentang Guru dan Dosen ( Pasal 1 ) dinyatakan bahwa: " Guru adalah pendidikan professional dengan tugas utama mendidik, mengajar, memimbing, mengarahkan, menilai dan mengevaluasi peserta didik pada jalur pendidikan formal, pada jenjang pendidikan dasar dan pendidikan menengah".

\section{Pengertian Kinerja Guru}

Istilah kinerja berasal dari Job Performancelactual performance yang dapat diartikan sebagai pertasi kerja atau pretasi sesungguhnya yang dicapai oleh seseorang. Guru dapat mencapai kinerja yang maksimal jika guru mau berusaha untuk mengembangkan seluruh kompetensi yang dimilikinya dan juga memanfaatkan serta menciptakan situasi yang ada dilingkungan sekolah sesuai dengan aturan yang berlaku.

Anwar Prabu Mangkunegara mendefinisikan kinerja (prestasi kerja) sebagai hasil kerja secara kualitas dan kuantitas yang dicapai oleh seorang pegawai dalam melaksanakan tugasnya sesuai dengan tanggung jawab yang diberikan. Kemudian menurut Ivor $\mathrm{K}$ Davies mengatakan bahwa ada empat cirri 
seorang yang memiliki pekerjaan sebagai guru, cirri-ciri tersebut adalah (Musarofah, 2008):

1. Merencanakan, yaitu pekerjaan seorang guru menyusun tujuan belajar.

2. Mengorganisasikan, yaitu pekerjaan seorang guru mengatur dan menghubungkan sumber-sumber belajar sehingga dapat mewujudkan tujuan belajar dengan cara yang paling efektif, efesien, dan seekonomis mungkin.

3. Memimpin, yaitu pekerjaan seorang guru untuk memotivasi, mendorong, dan menstimulasikan murid-muridnya sehingga peserta didik siap mewujudkan tujuan belajar.

4. Mengawasi, yaitu pekerjaan seorang guru untuk menentukan apakah fungsinya dalam mengorganisasikan dan memimpin di atas telah berhasil dalam mewujudkan tujuan yang telah dirumuskan.

\section{Indikator Kinerja Guru}

Ada beberapa indicator yang dapat dilihat sebagai peran guru dalam meningkatkan kemampuan peserta didik agar dapat menerima materi pembelajaran yang baik melalui proses belajar mengajar yang diadakannya.

Indikator-indikator kinerja tersebut adalah :

1. Perencanaan Kegiatan Pembelajan

2. Pelaksanaan Kegiatan Pembelajaran

3. Evaluasi Hasil Pembelajaran.

\section{METODE PENELITIAN}

\section{Objek Penelitian}

Adapun penelitian ini dilakukan Sekolah Dasar (SD) Negeri di Kota Bandar
Lampung, dengan jumlah 30 sekolah dan 67 orang guru kelas enam yang sudah bersertifikasi. Penelitian dilaksanakan bulan April 2017.

\section{Metode dan Teknik Pengumpulan Data}

Dalam penelitian ini jenis data yang diperlakukan adalah :

a. Data Primer

Data primer merupakan data dasar yang akan diperoleh langsung tanpa perantara orang atau lembaga lain sebagai pihak ketiga. Data primer ini diperoleh dengan wawancara melalui responden dengan menggunakan daftar pertanyaan.

b. Data Sekunder

Data skunder merupakan data yang diperoleh melalui orang lain yang berhubungan dengan permasalahan yang dipecahkan. Data sekunder ini diperoleh melalui cara studi dokumenter yaitu mengumpulkan dan mempelajari brosurbrosur serta dokumen organisasi.

Adapun teknik yang digunakan dalam pengumpulan data adalah dengan :

1. Observasi, yaitu mengadakan survey atau pengamatan langsung kelokasi penelitian.

2. Interview atau wawancara, yaitu mengadakan tanya jawab langsung dengan guru SD yang sudah sertifikasi.

3. Dokumentasi, yaitu mengumpulkan dan mencatat dokumentasi yang relevan.

4. Quisioner, yaitu membuat pertanyaan yang berhubungan dengan variabel penelitian.

\section{Sampel dan Populasi}

Jumlah Sekolah Dasar Negeri di Kota Bandar Lampung terdiri dari 187 sekolah 
dengan jumlah guru yang sudah bersertifikasi sebanyak 2.340 guru . Dari sejumlah sekolah tersebut penulis mengambil sampel sebesar $15 \%$ (Arikunto, 2015) sehingga Sekolah Dasar Negeri yang menjadi sampel sebanyak 30 sekolah dan dari 30 sekolah tersebut jumlah guru kelas VI (enam) yang sudah bersertifikasi sebanyak 67 guru, karena guru kelas VI ( enam) berkaitan dengan nilai UAS ( Ujian Akhir Sekolah ). Oleh karna perhitungan yang dilakukan regresi linier sederhana.

\section{Metode Analisis Data}

Analisa data adalah proses penyederhanaan data ke dalam bentuk yang lebih mudah dibaca dan dipahami serta diinterpretasikan melalui kalimat (Singarimbun, 2015). Pada penelitian ini, analisa data yang digunakan adalah analisis data kualitatif dan analisis data kuantitatif.

Persamaan Regresi Linear Sederhana menentukan persamaan regresi linear sederhana untuk X :

$$
Y=a+b X+e
$$

Keterangan:

$$
\begin{aligned}
& \mathrm{Y}=\text { Kinerja guru } \\
& \mathrm{a}=\text { Konstanta } \\
& \mathrm{b}=\text { Koefisien regresi } \mathrm{X} \\
& \mathrm{X}=\text { Sertifikasi } \\
& \mathrm{e}=\text { Faktor kesalahan }
\end{aligned}
$$

Untuk mengetahui besarnya pengaruh, penghitungan koefisien korelasi tersebut kemudian dilanjutkan dengan Rumus Koefisien Determinasi atau Koefisien Penentu (KP):

$$
K P=(r)^{2} x 100 \%
$$

Untuk menguji secara hipotesis secara parsial digunakan Uji t dengan rumus :

$$
t_{\text {hitung }}=\frac{r \sqrt{N-2}}{\sqrt{1-r^{2}}}
$$

Keterangan:

$$
\begin{array}{ll}
\mathrm{t}_{\text {hitung }} & =\text { Nilai } \mathrm{t} \\
\mathrm{r} & =\text { Koefisien Korelasi } \\
\mathrm{N} & =\text { Jumlah responden }
\end{array}
$$

Kriteria untuk Uji $\mathrm{t}$ adalah sebagai berikut :

a) Jika $t_{\text {hitung }}>t_{\text {tabel }}$ maka Ha diterima dan Ho ditolak.

b) Jika $t_{\text {hitung }} \leq \mathrm{t}$ tabel maka Ha ditolak dan Ho diterima.

\section{HASIL DAN PEMBAHASAN}

Berdasarkan data yang diperoleh dari olah data variabel tunjangan sertifikasi diketahui total skor jawaban maximum dari 67 orang responden adalah 48 dan jawaban minimum adalah 23 , sedangkan rata - rata jawaban adalah 36,32. Untuk variabel kinerja guru diketahui total skor jawaban maximum dari 67 orang responden adalah 47 dan jawaban minimum adalah 23, sedangkan rata - rata jawaban adalah 35,40 .

Uji validitas menunjukkan bahwa bahwa semua butir kuesioner variabel tunjangan sertifikasi memiliki nilai Corrected Item Total Correlation yang lebih besar dari nilai $r$ tabel yaitu 0,240 dengan demikian semua butir kuesioner dinyatakan valid dan semua butir kuesioner variabel kinerja guru memiliki nilai Corrected Item Total Correlation yang lebih besar dari nilai $r$ tabel yaitu 0,240 dengan demikian semua butir kuesioner dinyatakan valid.

Hasil uji reliabilitas menunjukkan bahwa masing - masing item butir kuesioner untuk varibel sistem informasi (X) dinyatakan reliabel karena memiliki nilai Cronbach's alpha 0,922 atau >0,60.

Determinan atau $\mathrm{R}$ Square digunakan untuk melihat berapa besar variabel 
independent. Dengan kata lain koefisien determinan digunakan untuk mengukur kemampuan variabel tunjangan sertifikasi (X) mampu menjelaskan variabel kinerja guru $(\mathrm{Y}) . \mathrm{R}=0,449$ yang berarti pengaruh antara variabel tunjangan sertifikasi terhadap variabel kinerja guru memiliki tingkat koefisien korelasi yang kuat dengan nilai sebesar $44,9 \%$.

Adjusted $R$ Square sebesar 0,189 yang berarti kinerja guru dapat dijelaskan oleh tunjangan sertifikasi sebesar 18,9\%, sedangkan sisanya sebesar $75,4 \%$ dapat dijelaskan oleh faktor - faktor lain yang tidak diteliti dalam penelitian ini. $R$ Square sebesar 0,202 atau 20,2\% kinerja guru dapat dijelaskan oleh tunjangan sertifikasi, sedangkan sisanya $79,8 \%$ dapat dijelaskan oleh faktor - faktor lain yang tidak diteliti dalam penelitian ini. Std. Error the Estimate (standar deviasi) sebesar 5,57 yang berarti model dinilai cukup karena apabila nilai standar deviasi semakin kecil berarti model akan semakin baik.

Persamaan regresi yang diperoleh adalah $\mathrm{Y}=20,924+0,435 \mathrm{X}+\mathrm{e}$. Konstanta, sebesar 20,924 artinya jika tunjangan sertifikasi (X) nilainya tetap maka kinerja guru (Y) nilainya adalah 20,924. Koefisien regresi tunjangan sertifikasi (X) sebesar 0,435 artinya jika variabel tunjangan sertifikasi (X) mengalami kenaikan 1 satuan maka kinerja guru (Y) akan naik sebesar 0,435 dengan asumsi variabel independen lainnya nilainya tetap. Maka variabel tunjangan sertifikasi berpengaruh positif terhadap kinerja guru dan memiliki hasil yang signifikan karena nilai signifikansi lebih kecil dari 0,05 yaitu 0,00 .

Hasil dari uji koefisien determinasi menunjukkan bahwa variabel tunjangan sertifikasi (X) dapat menjelaskan variabel kinerja guru (Y). Dengan demikian Dinas Pendidikan perlu memperhatikan aspek tunjangan sertifikasi yang ada di lingkungan Dinas Pendidikan dan
Kebudayaan Kota Bandar Lampung. Dari hasil uji analisis linier sederhana dapat dikaitkan dengan hipotesis awal peneliti yaitu terdapat pengaruh yang positif dan signifikan tunjangan sertifikasi (X) terhadap kinerja guru (Y) pada SD Negeri Kota Bandar Lampung. diterima karena terdapat pengaruh positif dan memiliki $\mathrm{t}_{\text {hitung }}$ sebesar 4,051 yang lebih besar dari $t_{\text {tabel }}$ 1,669 dan signifikan karena diperoleh nilai signifikansi $<0,05$ yaitu sebesar 0,00 .

\section{KESIMPULAN DAN SARAN}

\section{Kesimpulan}

Dari hasil analisis data dan pembahsan dapat disimpulkan bahwa terdapat pengaruh tunjangan sertifikasi terhadap kinerja di Kota Bandar Lampung. Hasil perhitungan uji koefisien determinasi $\left(\mathrm{R}^{2}\right)$ yang menunjukkan bahwa adanya pengaruh yang tinggi antara variable sertifikasi guru terhadap kinerja guru. Pengaruh kedua variable yang diteliti ini menunjukkan nilai sebesar 0.449 atau sebesar 44,9\%. Angka tersebut mempunyai arti bahwa 44,9\% variabilitas kinerja guru yang terjadi dapat dijelaskan dengan variable sertifikasi guru.

\section{Saran}

Untuk lebih meningkatkan kinerja guru SD di Kota Bandar Lampung yang telah lulus sertifikasi diharapkan untuk :

1. Menjadi contoh bagi siswa maupun rekan kerja di sekolah maupun di masyarakat.

2. Mampu menyusun program kegiatan pembelajaran yang dilakukan oleh guru, yaitu mengembangkan silabus dan Rencana Pembelajaran (RPP) dengan baik.

3. Ketika proses pembelajaran guru selalu berusaha sebaik-baiknya untuk menciptakan pembelajaran yang 
kondusif, agar dapat tercapai tujuan pembelajaran yang diinginkan.

4. Meningkatkan kedisiplinan baik disiplin waktu maupun kedisiplinan mentaati peraturan yang ada.

5. Selalu bersungguh-sungguh dan bertanggung jawab terhadap tugas yang dibebankan kepadanya.

6. Berusaha menjadi guru yang professional dengan selalu meningkatkankemampuan yang dimilikinya.

\section{DAFTAR PUSTAKA}

Arikunto, Suharsimi. 2002. Prosedur Penelitian. Edisi Kelima. Jakarta: Penerbit Bineka Cipta.

Anif, Sofyan. 2012. Implementasi Funsi Manajemen Pendidikan terhadap Profesionalitas Guru ( Sebuah Kajian Implementasi Sertifikasi Guru dalam Jabatan ). Jurnal Varia Pendidikan. Vol.24.

Depdiknas, 2009. Sertifikasi Guru dalam Jabatan Tahun 2013. Http:// psg15.um.ac.id/lrafletsertifikasi.pdf.

Gustina Lesy. Pengaruh Sertifikasi Terhadap Kineja Guru SDN 2 Tanjung Senang Bandar lampung Skripsi.

Istiarini, Risma, dan Sukanti. 2012. Pengaruh Sertifikasi Guru dan Motivasi Kerja Guru Terhadap Kinerja Guru SMA N 1 Sentolo Kabupaten Kulon Progo. Jurnal Pendidikan Akutansi Indonesia. Vol.10, No.01. Pp 98-113.

Kemendikbud 2013. Panduan Penetapan Peserta Program Sertifikasi Tahun 2013.Http:/bpsdmk.kemendikbud.go $. i d / p f$.
Payong, Marsel R. 2011. Sertifikasi Profesi Guru. Jakarta: Indeks.

Prasetyo, Bambang dan Lina Miftahul Jannah. 2012. Metode Penelitian Kuantitatif: Teori dan Aplikasi. Jakarta: Rajawali Pers.

Singarimbun, Masri dan Sofyan Effendi 2015. Metode Penelitian Survey ( Edisi Revisi). Jakarta: LP3ES.

Sugiyono. 2010. Metode Penelitian Kuantitatif dan Kualitatif dan $R \& D$. Bandung : CV.Alpha Beta.

Sulistyani, AT. 2003. Manajemen Personalia. Yogyakarta: Graha Ilmu.

West, Richard. 2002. Pengantar Teori Komunikasi: Analisis dan Aplikasi. Jakarta: Salemba Empat. 